\title{
Origin of Drusy Dolomite Cement in Permo-Triassic Dolostones, Northern United Arab Emirates
}

\author{
Howri Mansurbeg 1,2,*, Mohammad Alsuwaidi ${ }^{3} \mathbb{D}$, Shijun Dong ${ }^{3}$, Salahadin Shahrokhi ${ }^{4}$ and Sadoon Morad $^{3}$ \\ 1 General Directorate of Scientific Research Center, Salahaddin University-Erbil, \\ Erbil 44001, The Kurdistan Region, Iraq \\ 2 School of the Environment, University of Windsor, Windsor, ON N9B 3P4, Canada \\ 3 Department of Earth Sciences, Khalifa University, Abu Dhabi 51133, United Arab Emirates; \\ mohammad.alsuwaidi@ku.ac.ae (M.A.); dongshijun@yahoo.com (S.D.); sadoon.morad@ku.ac.ae (S.M.) \\ 4 URGA, s.r.o., Hydrogeologie, Geologie a Životní Prostředí, Sanace, 77200 Olomouc, Czech Republic; \\ salah_sh1994@yahoo.com \\ * Correspondence: howri.mansurbeg@uwindsor.ca; Tel.: +45-42754220
}

Citation: Mansurbeg, H.; Alsuwaidi, M.; Dong, S.; Shahrokhi, S.; Morad, S. Origin of Drusy Dolomite Cement in Permo-Triassic Dolostones, Northern United Arab Emirates. Water 2021, 13, 1908. https://doi.org/10.3390/ w13141908

Academic Editor:

Kristine Walraevens

Received: 4 June 2021

Accepted: 6 July 2021

Published: 9 July 2021

Publisher's Note: MDPI stays neutral with regard to jurisdictional claims in published maps and institutional affiliations.

Copyright: (c) 2021 by the authors. Licensee MDPI, Basel, Switzerland. This article is an open access article distributed under the terms and conditions of the Creative Commons Attribution (CC BY) license (https:// creativecommons.org/licenses/by/ $4.0 /)$.

\begin{abstract}
While the characteristics and origin of drusy calcite cement in carbonate deposits is well constrained in the literature, little attention is paid to drusy dolomite cement. Petrographic observations, stable isotopes, and fluid-inclusion microthermometry suggest that drusy dolomite cement in Permo-Triassic conglomerate/breccia dolostone beds in northern United Arab Emirates has precipitated as cement and not by dolomitization of drusy calcite cement. The low $\delta^{18} \mathrm{O}_{\mathrm{VPDB}}$ $(-9.4 \%$ o to $-6.2 \%$ ) and high homogenization temperatures of fluid inclusions in drusy dolomite $\left(\mathrm{T}_{\mathrm{h}}=73-233^{\circ} \mathrm{C}\right)$ suggest that dolomitization was caused by hot basinal brines (salinity $=23.4 \mathrm{wt} \%$ $\mathrm{NaCl}$ eq.). The $\delta^{13} \mathrm{C}_{\mathrm{VPDB}}$ values ( $+0.18 \%$ o to $+1.6 \%$ ) and ${ }^{87} \mathrm{Sr} /{ }^{86} \mathrm{Sr}$ ratio (0.708106 to 0.708147 ) indicate that carbon and strontium were derived from the host marine Permo-Triassic carbonates. Following this dolomitization event, blocky calcite $\left(\mathrm{T}_{\mathrm{h}}=148{ }^{\circ} \mathrm{C}\right.$; salinity $=20.8 \mathrm{wt} \% \mathrm{NaCl}$ eq. $)$ precipitated from the hot basinal brines. Unravelling the origin of drusy dolomite cement has important implications for accurate construction of paragenetic sequences in carbonate rocks and decipher the origin and chemistry of diagenetic waters in sedimentary basins.
\end{abstract}

Keywords: drusy dolomite; dolomitization; cementation; hot basinal fluids

\section{Introduction}

Calcite cement with a drusy mosaic texture, displaying crystal size growth from pore wall to pore center, is widely distributed in limestones [1,2]. Such cement commonly fills moldic pore and hence has been interpreted to be sourced by dissolution of aragonitic allochems [3-7]. The stable isotopic composition of drusy mosaic calcite cement coupled with the presence of moldic porosity have been interpreted to indicate a meteoric origin [8-10]. Dolomite cement in carbonate rocks commonly develops rhombic crystals that do not show systematic size variation within the pores [11]. Nevertheless, rare drusy mosaic dolomite cement has been reported in carbonate deposits too [12-15]. The origin of such dolomite is not fully explored, particularly regarding whether it is a primary precipitate or formed by dolomitization of precursor drusy calcite cement. The fluid flow and related diagenetic evolution, particularly dolomitization of carbonate succession in northern United Arab Emirates (UAE), is interpreted to be controlled by the tectonic evolution of the region $[16,17]$.

In this paper, we constrain the origin of drusy mosaic dolomite cement in conglomerates/breccia of the Bih Formation (Permo-Triassic), Ras Al Khaima, northern UAE (Figure 1), using petrographic, stable isotopic, and fluid-inclusion microthermometric analyses. This study provides important insights into the conditions of formation of drusy dolomite cement and its associated diagenetic fluids. The presented data and discussions 
help in constructing more accurate paragenetic sequences in Permo-Triassic dolostones, northern UAE, and in other carbonate successions with similar depositional and diagenetic settings.

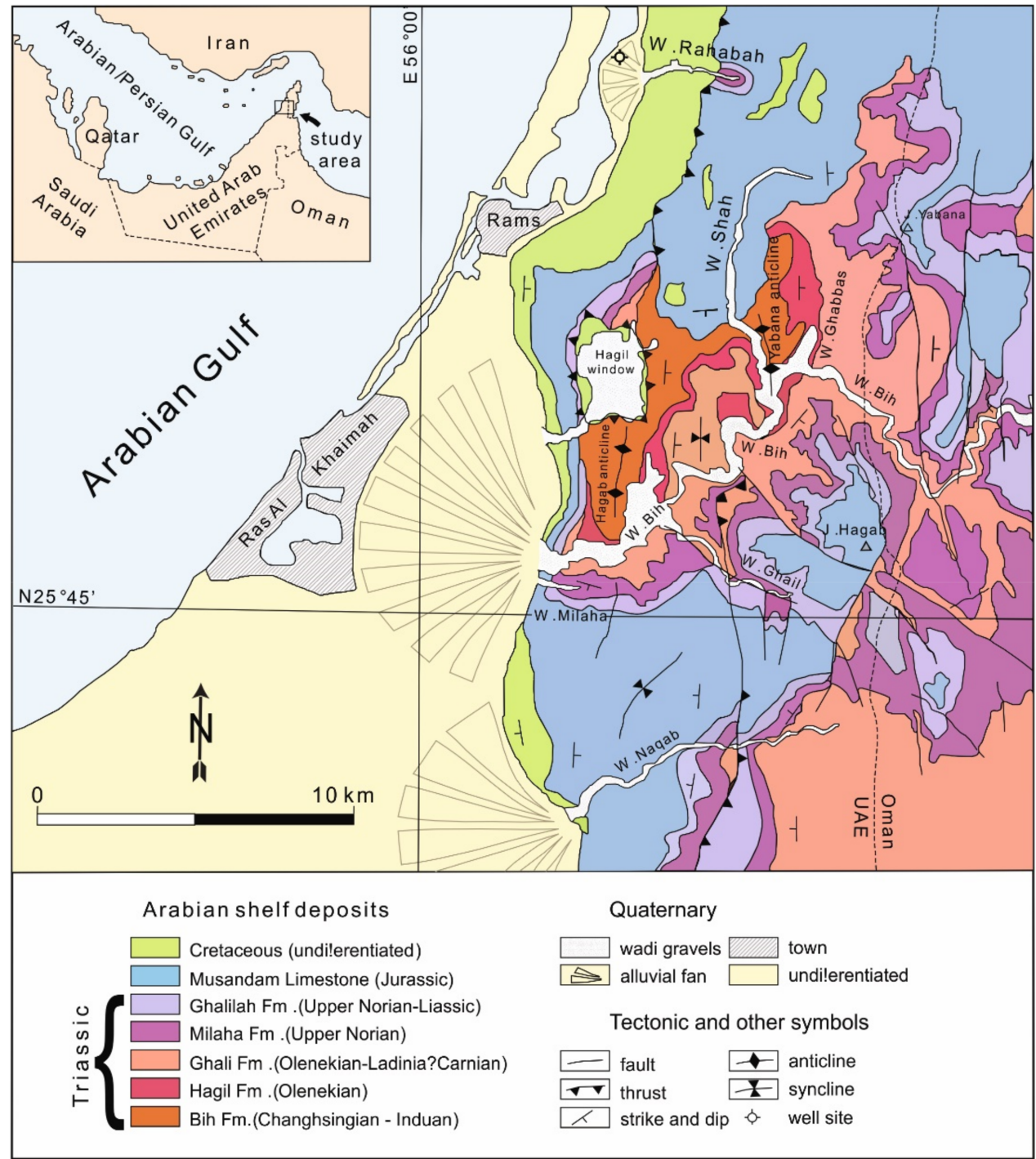

Figure 1. Location of the study area, northwest of the UAE (marked in green). Modified from [18-20].

\section{Geological Setting}

The Bih Formation (Permo-Triassic) crops out in the Musandam Peninsula, Ras Al Khaimah, northern United Arab Emirates (Figure 1). The formation is suggested to be age-equivalent to the Khuff Formation [19] which is an important hydrocarbon reservoir in the Arabian Gulf region. Deposition of the Bih Formation occurred in subtidal to intertidal (shoals, lagoon, and mudflats) environments on a passive margin of the Arabian plate [20].

The formation is divided into two units separated by a marker interval, which is called mid-Bih conglomerates/breccias [21]. The origin of this interval is uncertain, being interpreted to have resulted from the collapse of evaporite beds [20] tectonic deformation [20] or are lag deposits formed owing to marine transgression [22]. Strohmenger et al. [20] proposed that the Bih Formation corresponds to sequence KS4 through KS7 of the Khuff Formation (Figure 2). Two main tectonic events have affected the study area [23] including: (i) The obduction of Oman ophiolite on the Arabian platform during the Late Cretaceous. During this tectonic phase, the passive northeastern margin of the Tethys ocean became 
compressive and resulted in the close of the Tethys ocean [24]; (ii) the Zagros orogeny (Paleocene to Middle Miocene) [25-28] which caused large scale folding and thrusting [26].

$\underline{A}$

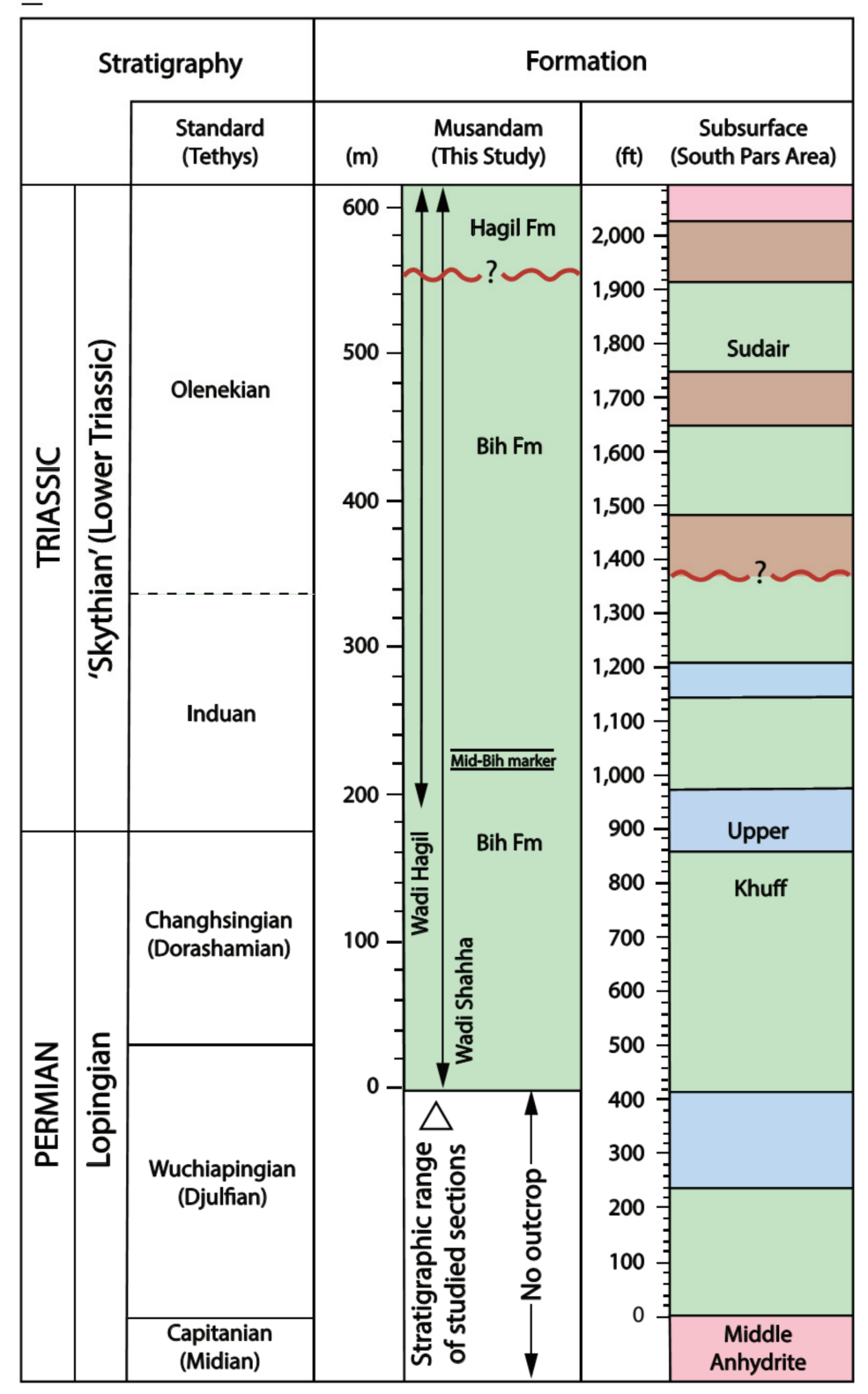

$\underline{B}$

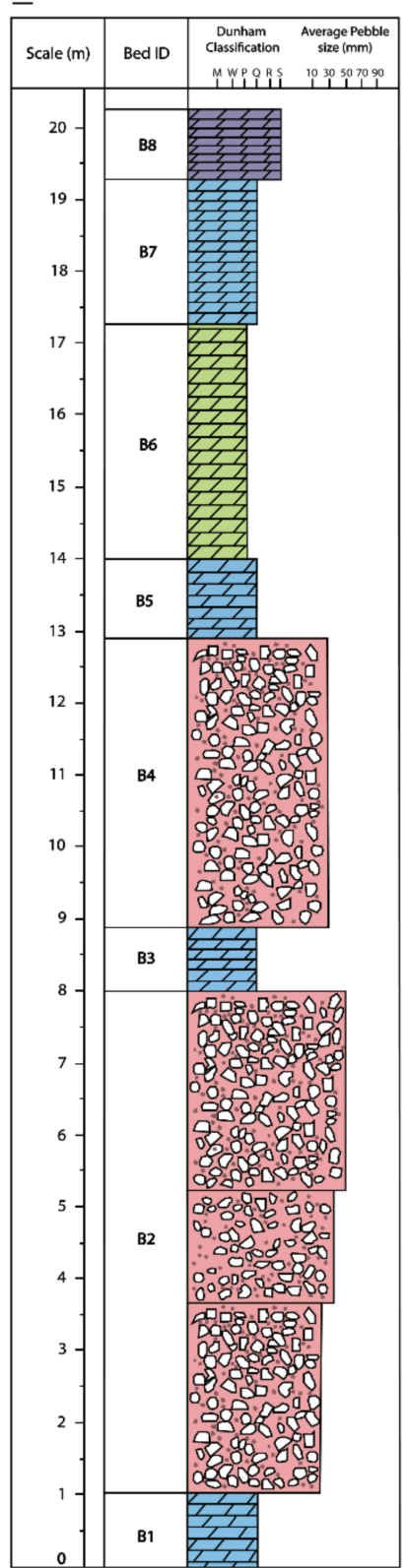

Figure 2. (A) Chronostratigraphic framework of the Khuff Formation in the subsurface compared to the stratigraphic range of the Bih Formation [21]. (B) Logging graph showing the thickness of conglomerate/breccia beds in the field.

\section{Samples and Methods}

Fifty-six samples were collected from the conglomerate/breccia beds and associated dolostone beds. Thin sections were prepared for all the samples after impregnation with blue epoxy. Representative polished uncovered thin sections were prepared and examined by a Technosyn Cold cathodoluminescence microscope (CL), backscattered electron imaging (BSEI), and energy dispersive X-ray analyses (EDS) attached to a Quanta scanning electron microscope. Fluid-inclusion microthermometry was conducted on two representative double polished $50 \mu \mathrm{m}$ thick sections using a pre-calibrated LINKAM THMS600G stage fitted onto the Nikon E600 microscope. 
Synthetic pure $\mathrm{H}_{2} \mathrm{O}$ and $\mathrm{CO}_{2}$ inclusions standard were used to calibrate the thermocouple. Both homogenization $\left(\mathrm{T}_{\mathrm{h}}\right)$ and final ice melting temperatures $\left(\mathrm{Tm}_{\text {ice }}\right)$ were measured whenever the size of the inclusions permitted. The former is the minimum entrapment temperature of the inclusion (i.e., the temperature of mineral precipitation) [29]. The latter is the temperature at which the last ice melts in an aqueous fluid inclusion and reflects the trapped diagenetic fluid salinity [29]. The fluid salinity ( $\mathrm{wt} \% \mathrm{NaCl}$ eq.) was inferred from $\mathrm{Tm}_{\text {ice }}$ using the Bodnar equation [30]. In order to avoid overheating, low heating rates were used for measuring homogenization temperatures $\left(T_{h}\right)$.

Stable carbon and oxygen isotopes were obtained for the 36 micro-drilled drusy dolomite cement with a GVI IsoPrime continuous flow isotope ratio mass spectrometer system (CF-IRMS). The $\delta^{13} \mathrm{C}$ and $\delta^{18} \mathrm{O}$ isotopic values are determined on carbon dioxide $\left(\mathrm{CO}_{2}\right)$ from carbonate minerals by the reaction with $100 \%$ phosphoric acid $\left(\mathrm{H}_{3} \mathrm{PO}_{4}\right)$ at $90{ }^{\circ} \mathrm{C}$ in a vacuum using standard procedures based on the principles reported in [31]. Samples and standards are weighed into Exetainer ${ }^{\mathrm{TM}}$ septum vials, sealed and flushed with pure helium. In addition, $100 \%$ phosphoric acid is injected into the vial, which is then placed in an aluminum tray maintained at $90{ }^{\circ} \mathrm{C}$ for more than $1 \mathrm{~h}$. The $\mathrm{CO}_{2}$ is extracted automatically with a double-hole needle Gilson auto-sampler connected to a GVI MultiFlow. The MultiFlow contains a 500-uL sample loop, and a GC column that separates $\mathrm{CO}_{2}, \mathrm{~N}_{2}, \mathrm{O}_{2}$, and $\mathrm{H}_{2} \mathrm{O}$. Helium carrier gas then transports the purified $\mathrm{CO}_{2}$ into the GVI IsoPrime continuous flow isotope ratio mass spectrometer system (CF-IRMS) that measures the isotope ratios. Four representative micro-drilled drusy dolomite cement samples were analyzed for $\mathrm{Sr}$ isotopes. One $\mathrm{mg}$ of each sample is collected to react with suprapure $\mathrm{HCl}$ for $24 \mathrm{~h}$. Purified $\mathrm{Sr}$ is obtained by chromatographic separation with $2.5 \mathrm{~mL}$ of AGW $50 \times 8$ (Biorad) cation exchange resin [32]. The analysis equipment is a Finnigan MAT 262 7-collector solid-source mass spectrometer with a single Re filament applying $1 \mu \mathrm{L}$ of ionization enhancing solution [32].

\section{Results}

\subsection{Field Observations}

The base of the Bih Formation does not crop out, and the lowest stratigraphic part consists of a medium-to-thick-bedded brown dolomitized packstone-grainstones with locally well-developed coarse-crystalline dolostone and vuggy textures. About $180 \mathrm{~m}$ above the base of the exposed Bih Formation, the mid-Bih conglomerate/breccia occurs (approx. $20 \mathrm{~m}$ thick; Figures 2B and 3A). The conglomerate/breccia beds of Wadi Bih, which are interbedded with dolograinstones, are massive overall but locally show a low-angle, through cross stratification (Figure 3B). The beds are cross cut by a series of normal faults (Figure 3A). The basal contact between conglomerate/breccia and underlying dolograinstone beds is sharp and erosional (Figure 3C). The lower contact between dolograinstone beds with the conglomerate/breccia beds is marked by the presence of rip-up dolomudstone intraclasts (Figure 3D).

Stylolites occur within as well as along boundaries between the conglomerate/dolostone beds. Above the mid-Bih breccia, there are cycles of interbedded dolostones and dolomitic limestones, with algal laminations, bird-eye structures, and dissolution molds. The succession continues with $90 \mathrm{~m}$ cliff-forming, dark gray coarse-crystalline dolostones. 

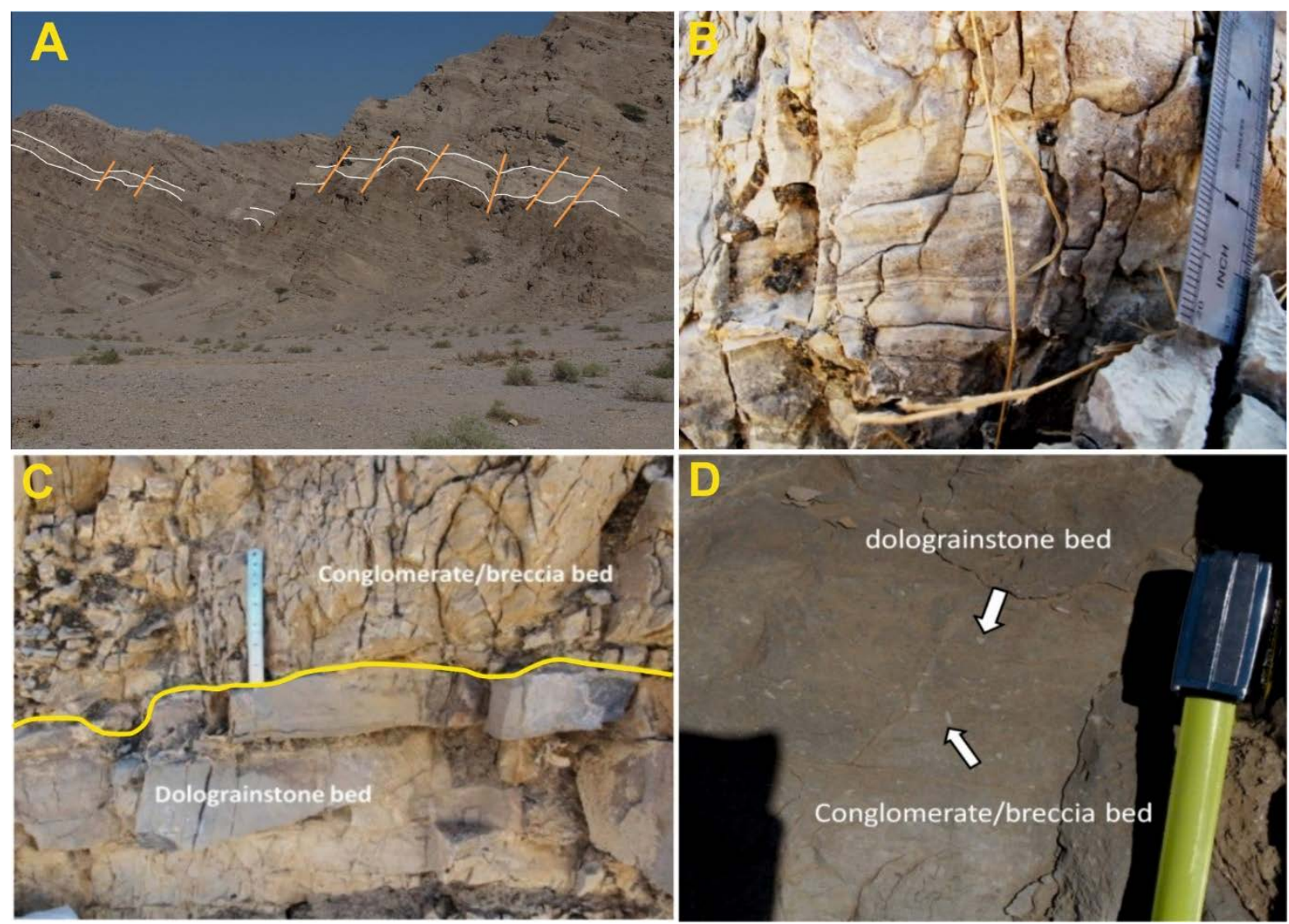

Figure 3. Field photographs showing: (A) The conglomerate/breccia beds are cut across by a series of normal faults, the conglomerate/breccia beds are shown by white lines, the faults are shown by orange lines. (B) Parallel lamination occurs at $14 \mathrm{~cm}$ above the basal contact in the conglomerate/breccia beds. (C) The contact (yellow line) between conglomerate/breccia and underlying massive dolostone bed. (D) The conglomerate/breccia beds have a gradational contact with overlying dolograinstone bed (arrows).

\subsection{Petrography of the Drusy Dolomite}

The conglomerate/breccia dolostone beds are cemented by drusy mosaic dolomite with a crystal size increasing progressively from $20 \mu \mathrm{m}$ along the pore wall to $2 \mathrm{~mm}$ in the pore center (Figure $4 \mathrm{~A}-\mathrm{D}$ ). In some cases, the centermost parts of the pore are occupied by blocky calcite (500-700 $\mu \mathrm{m}$ across). Dolomite crystals adjacent to this blocky calcite are partly calcitized (Figure 5A,B). The drusy dolomite crystals display sector CL zoning with alternating non-luminescent and bright orange luminescent zones (Figure 5C,D). The microcrystalline equant to bladed dolomite crystals (20-100 $\mu \mathrm{m}$ across) along the pore walls are dull luminescent. The blocky calcite crystals are dull luminescent with a local thin orange luminescent zone.

Dull luminescent calcite occurs along stylolites and fills fractures varying in width from 5 to $60 \mu \mathrm{m}$ (Figure 5E,F). The stylolites (amplitudes up to $2 \mathrm{~cm}$ ) and dissolution seams cut across the dolostone pebbles and have bed-parallel and bed-oblique orientations. Some of the stylolites are cutting across both pebbles and dolomite between pebbles (Figure 6A-D). The drusy mosaic dolomite has Fe and Mn contents below the EDS detection limits. Fe and Mn contents as low as few ppm can still generate zoning in dolomite [33-35]. 

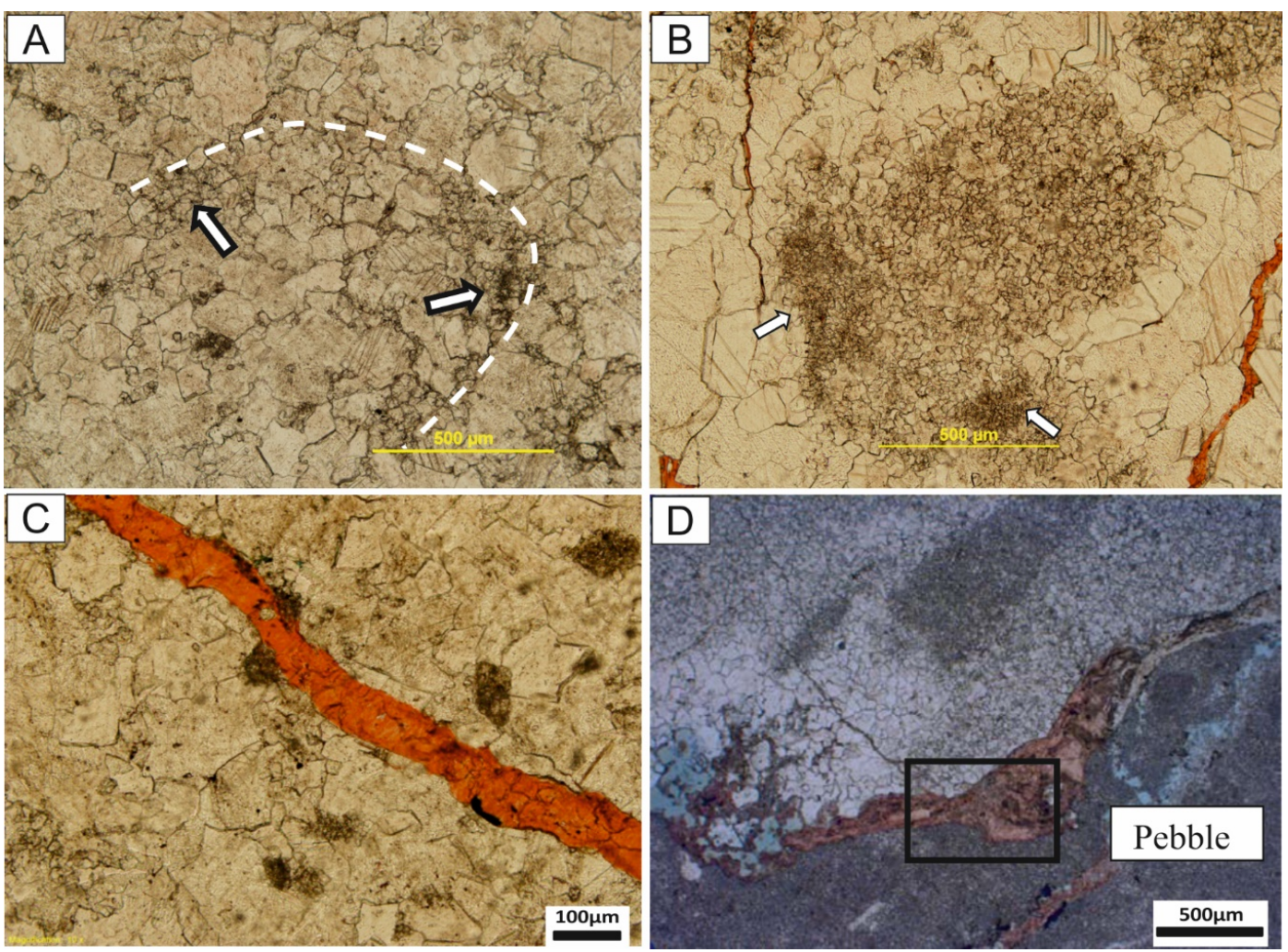

Figure 4. Optical photomicrographs (PPL) showing: (A) The fine dolomite crystals (arrows) in mosaic dolomite between pebbles are considered to be relics of fine-crystalline dolostone pebbles. The distribution of the fine dolomite crystals shows the rounded shape of pebble (dashed line). (B) The fine-crystalline dolostone pebble is partly replaced by the medium-crystalline dolomite $(40 \mu \mathrm{m})$. Parts (arrows) of the pebble are not subjected to replacement. (C) Fracture cutting across the mosaic dolomite cement between pebbles was filled by the mosaic calcite cement ( 5 to $60 \mu \mathrm{m}$ ). The average width of this fracture is $70 \mu \mathrm{m}$. (D) Fracture-filling calcite along a pebble.

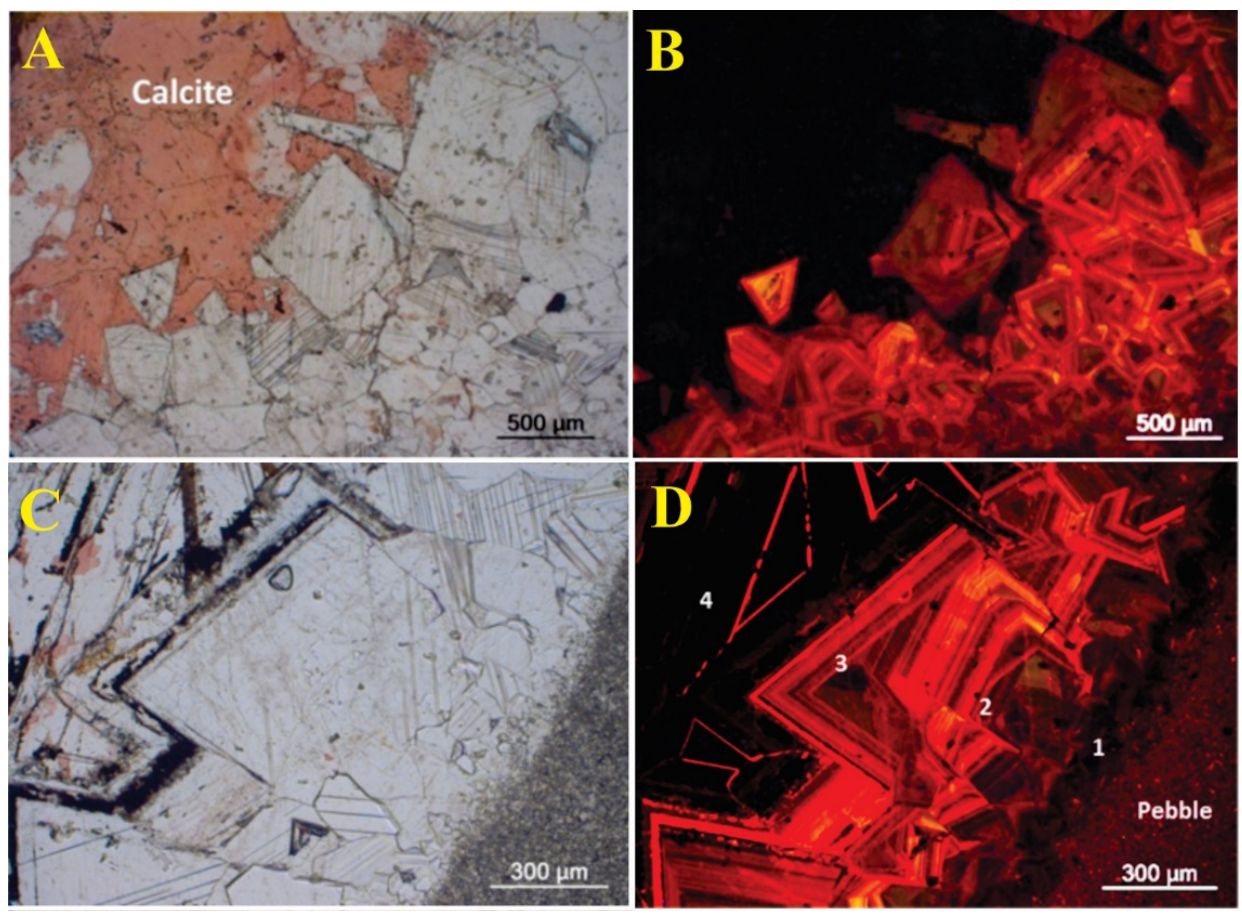

Figure 5. Cont. 

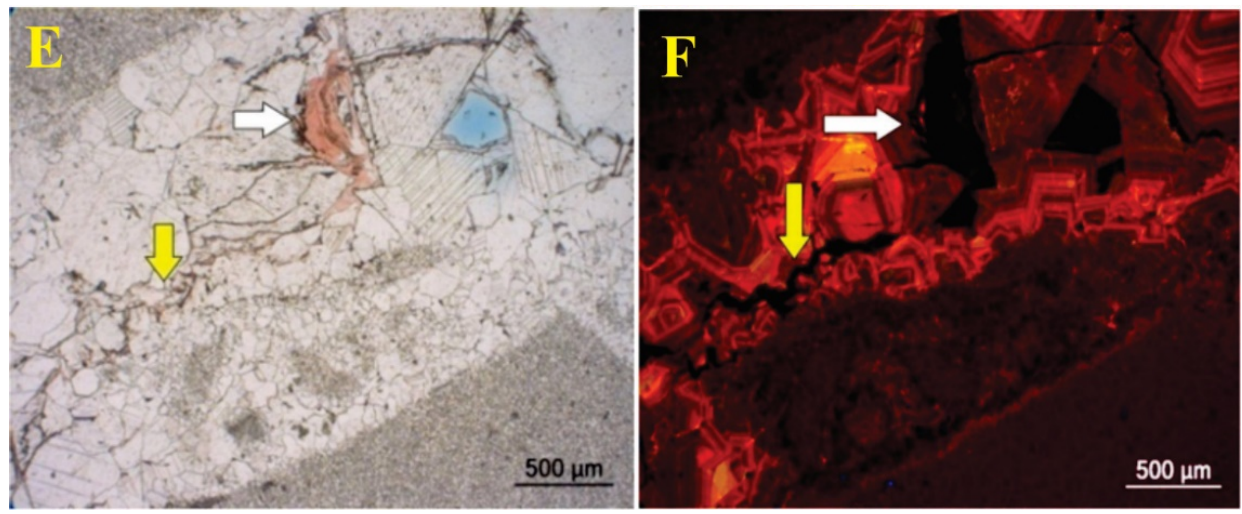

Figure 5. Optical (A; PPL) and companion CL (B) photomicrographs showing several generations of dolomite cement, which filled intergranular pores between pebbles are characterized by a distinguishable luminescent degree. Optical (C; PPL) and companion CL (D) photomicrographs showing: Coarse mosaic dolomite cement and coarse calcite cement, which is reddish stained in intergranular pores between pebbles; concentric growth pattern of planar-e to planar-s mosaic dolomite and non-luminescent calcite cements precipitated in pore space, where precursor dolomite was dissolved. Four generations of dolomite cement have been identified in the companion CL (D) photomicrograph. Optical (E; PPL) and companion CL photomicrographs (F) showing the calcite precipitated in intercrystalline pores between pebbles (white arrow) and within stylolite (yellow arrow) is characterized by a non-luminescent zone.
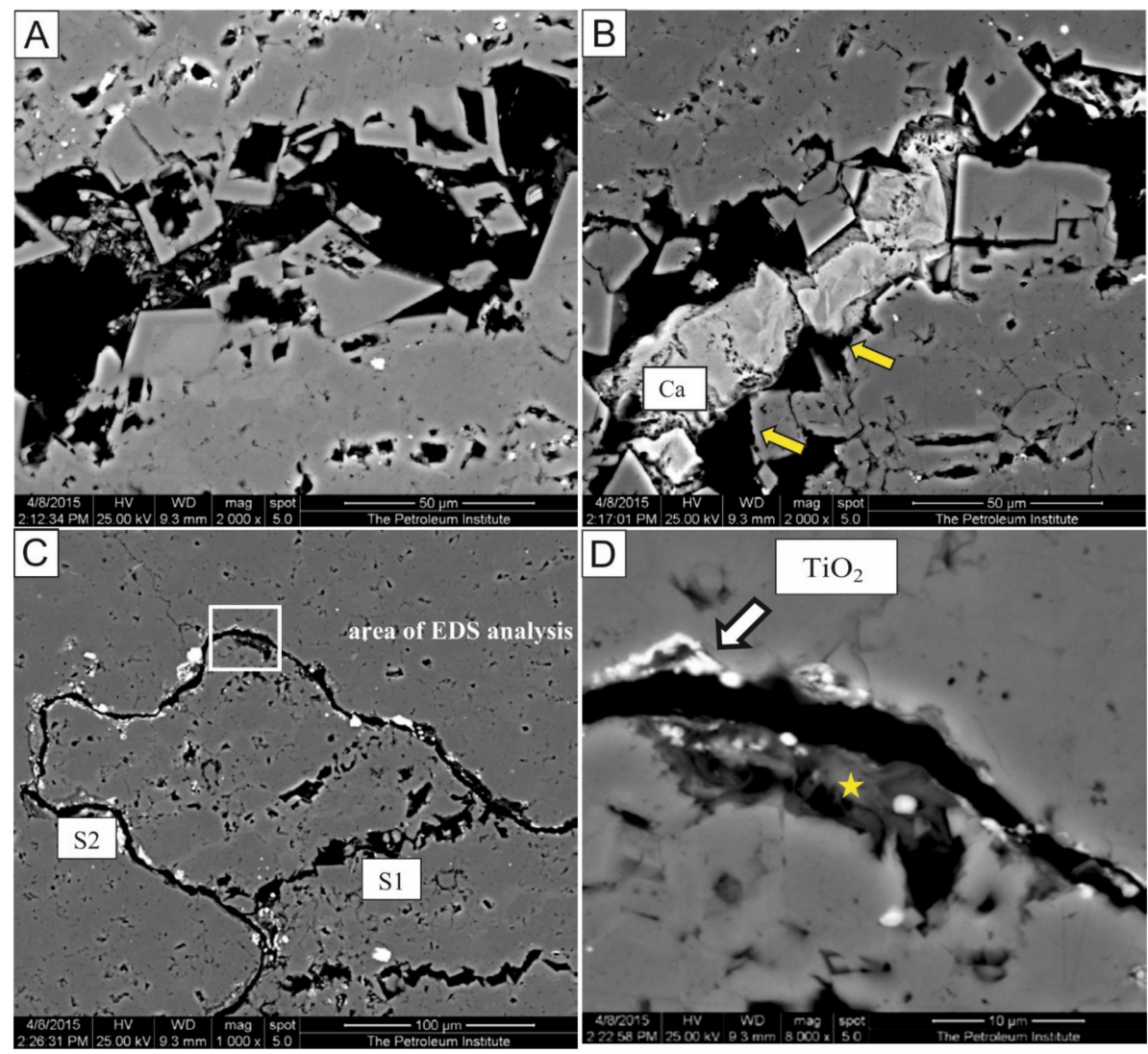

Figure 6. BSE images showing: (A) The presence of dolomite along a dissolution seam within a pebble. The core of rhombic dolomite crystals is dissolved while the rim is preserved. (B) Calcite cement (Ca) along the dissolution seam within the pebble, which precipitates after dissolution of dolomite (shown by an irregular boundary of dolomite crystal, yellow arrows). (C,D) stylolite/seams (S1 and S2) cutting across each other and the clay mineral and $\mathrm{TiO}_{2}$ occur along the stylolite/solution seam within a pebble. 


\section{3. $\mathrm{C}, \mathrm{O}$, and Sr Isotopic Composition of Dolomite Cement}

The $\delta^{13} \mathrm{C}_{\mathrm{VPDB}}$ values of drusy dolomite vary from $+0.2 \%$ to $+1.6 \%$ and $\delta^{18} \mathrm{O}_{\mathrm{VPDB}}$ from $-9.4 \%$ to $-6.2 \%$. The $\delta^{13} \mathrm{C}_{\mathrm{VPDB}}$ values of fracture-filling calcite cement vary between $-3.8 \%$ and $+1.9 \%$ and $\delta^{18} \mathrm{O}_{\text {VPDB }}$ from $-7.6 \%$ to $-4.0 \%$. The ${ }^{87} \mathrm{Sr} /{ }^{86} \mathrm{Sr}$ ratios of two drusy and mosaic dolomite samples are 0.708106 and 0.708147 , respectively (Figures 7 and $8 \mathrm{~A}, \mathrm{~B}$ ).

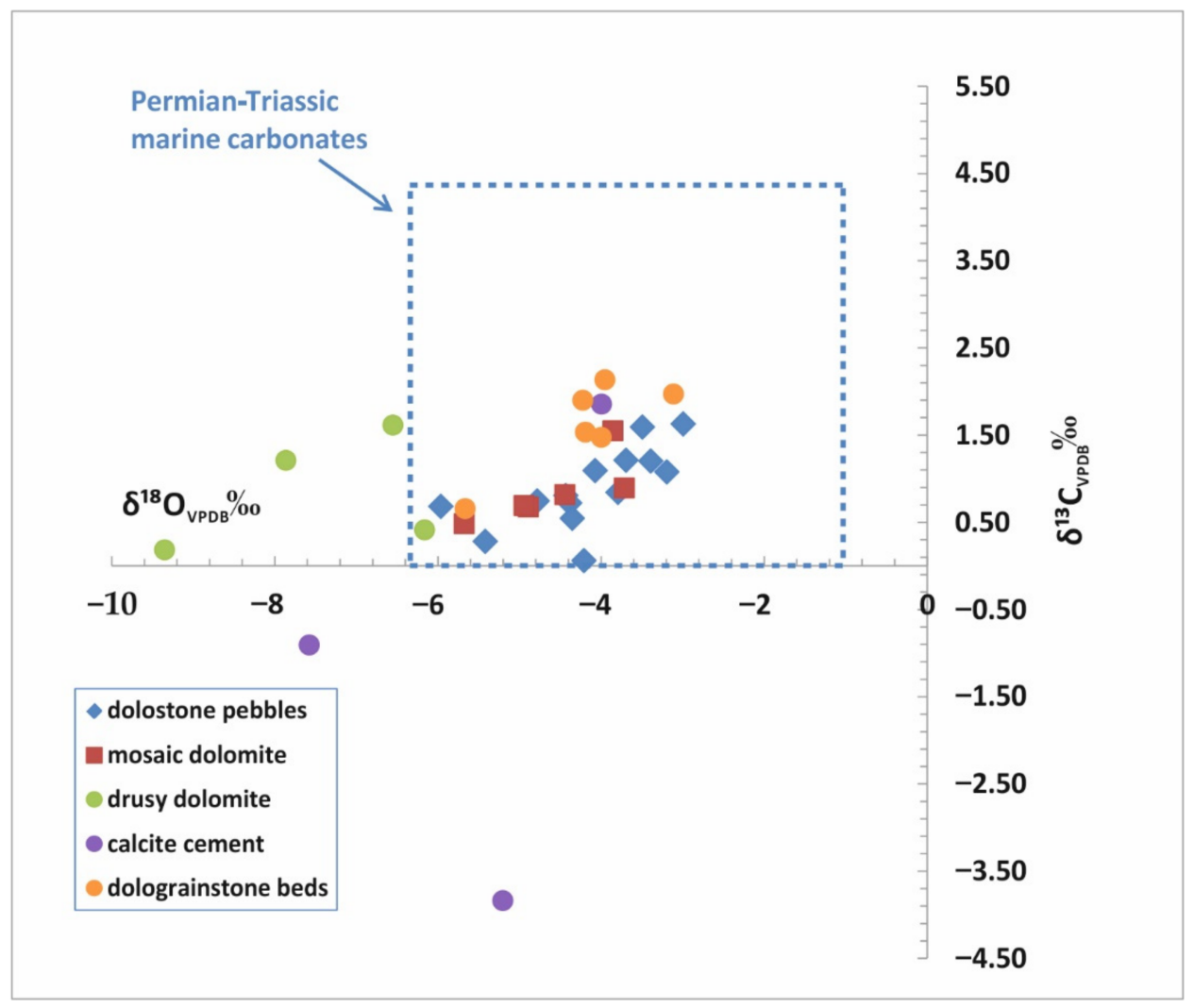

Figure 7. Cross plot of stable $\delta^{13} \mathrm{C}_{\text {VPDB }}$ versus $\delta^{18} \mathrm{O}_{\mathrm{VPDB}}$ values of samples from the conglomerate/breccia beds and the dolograinstone beds in the conglomerate/breccia interval, as well as isotope values of Permian to Triassic marine carbonates. Stable oxygen isotope values of drusy dolomite are lower compared to other dolomites and slightly lower than sea coeval marine carbonates.

\subsection{Fluid-Inclusion Microthermometry of Carbonate Cement}

Fluid inclusions (1-20 $\mu \mathrm{m}$ across) in the drusy mosaic dolomite cement display twophases (liquid and vapor). The crystal sizes of drusy dolomite are divided into fine $(50-100 \mu \mathrm{m})$, medium $(>100-500 \mu \mathrm{m})$, and coarse crystals $(>500 \mu \mathrm{m})$. Results can be summarized as follows: (1) Homogenization temperatures $\left(T_{h}\right)$ of fine-sized dolomite

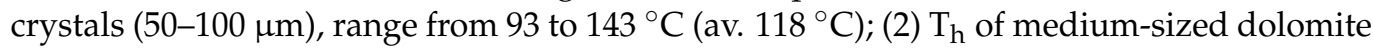
crystals $(100-500 \mu \mathrm{m})$ varies from 73 to $188^{\circ} \mathrm{C}$ (av. $130.5^{\circ} \mathrm{C}$ ). The salinity of these fluid inclusions could not be measured owing to the small size of the inclusions $(<2-3 \mu \mathrm{m})$; (3) $\mathrm{T}_{\mathrm{h}}$ values of coarse crystalline dolomite $(>500 \mu \mathrm{m})$ filling the centermost part of the pores vary from 118 to $233^{\circ} \mathrm{C}$ (av. $175.5^{\circ} \mathrm{C}$ ), while salinity ranges from 21.8 to $25.1 \mathrm{wt} \% \mathrm{NaCl}$ eq.; and (4) the calcite cement that postdates dolomite has a $\mathrm{T}_{\mathrm{h}}$ value of $148^{\circ} \mathrm{C}$ and salinity of $20.8 \mathrm{wt} \% \mathrm{NaCl}$ eq. The distribution of $\mathrm{T}_{\mathrm{h}}$ in calcite and drusy dolomite is shown in histograms (Figure 9). 


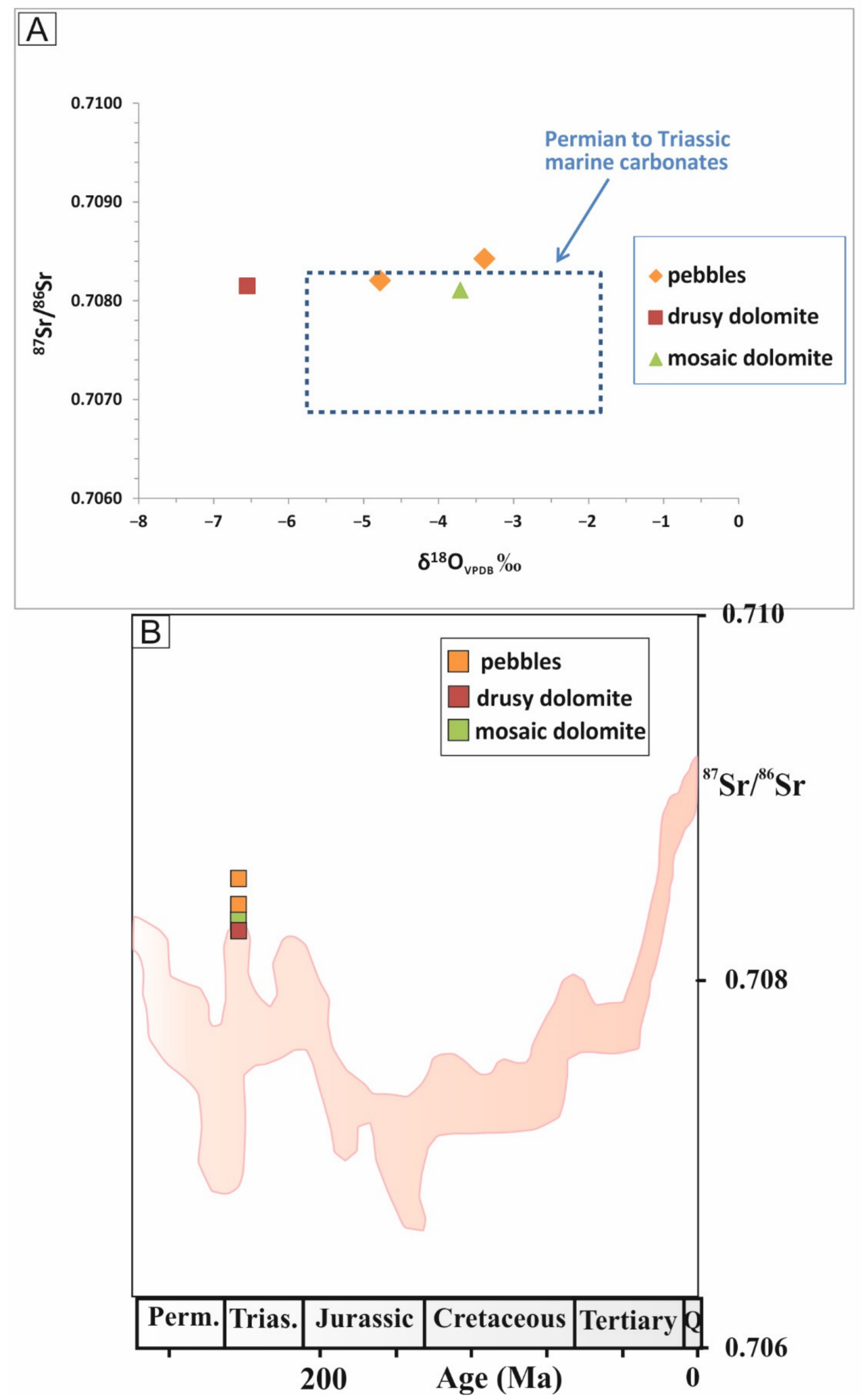

Figure 8. (A) Cross-plot of ${ }^{87} \mathrm{Sr} /{ }^{86} \mathrm{Sr}$ against $\delta^{18} \mathrm{O}_{\mathrm{VPDB}}$ showing two samples from the pebble have a slightly higher Sr isotope value than coeval marine carbonates. Two samples from drusy and mosaic dolomites are within the isotopic range of Permian to Triassic marine carbonates. The sample from drusy dolomite showing a lower $\delta^{18} \mathrm{O}_{\mathrm{VPDB}}$ value than coeval marine carbonates. (B) Measured ${ }^{87} \mathrm{Sr} /{ }^{86} \mathrm{Sr}$ ratios of different types of dolomite cements in the Bih Formation (Permo-Triassic) plotted on the sea water ${ }^{87} \mathrm{Sr} /{ }^{86} \mathrm{Sr}$ curve [31]. 


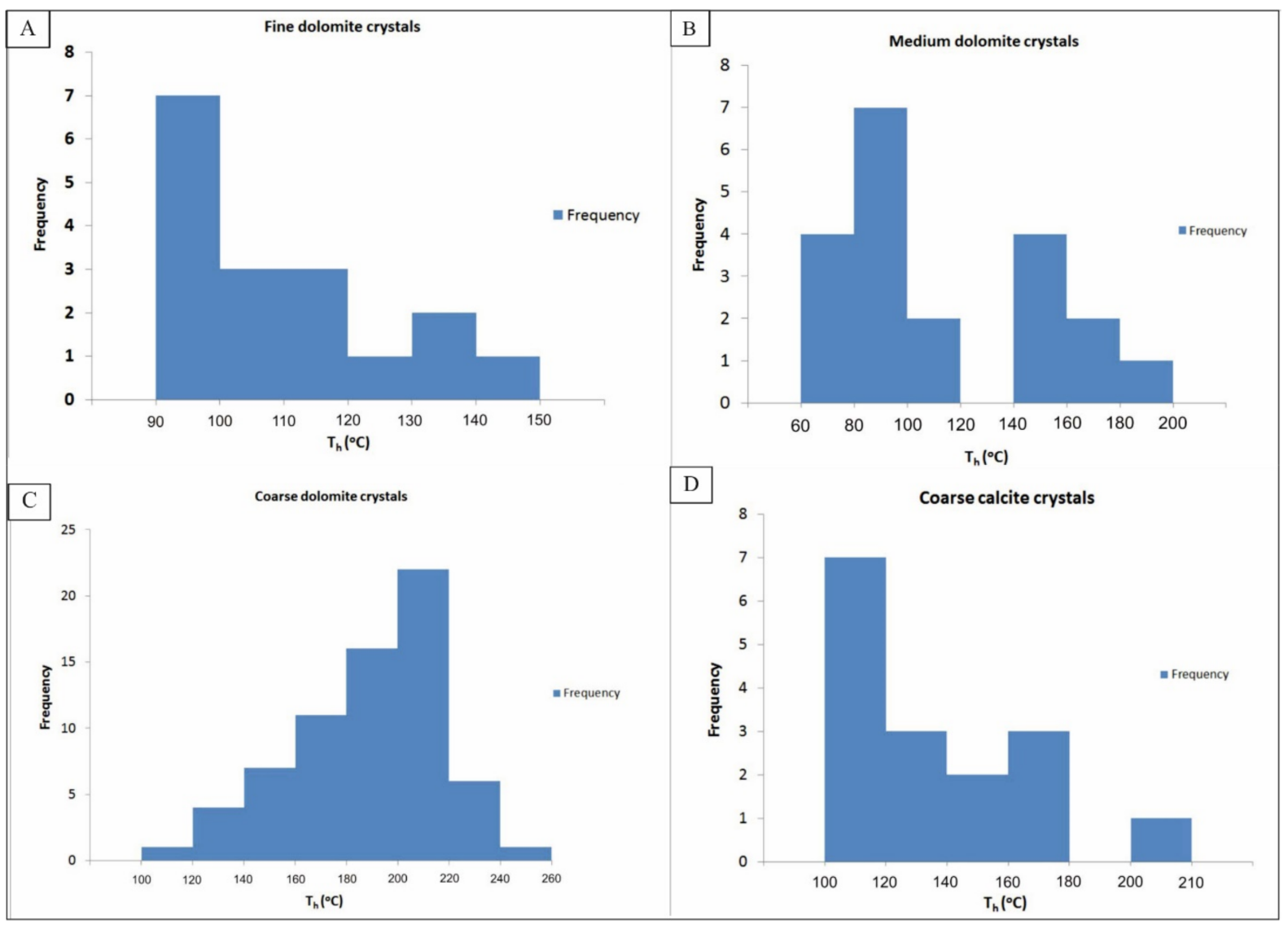

Figure 9. Histograms of fluid-inclusion homogenization temperatures $\left(\mathrm{T}_{\mathrm{h}}\right)$ in fine-crystalline dolomite (A), mediumcrystalline dolomite (B), coarse-crystalline dolomite (C), and calcite (D).

\section{Discussion}

Constraining the origin of the drusy dolomite in terms of whether it has been precipitated as cement, which is a common cement in limestones $[13,14]$ or formed by the replacement of precursor drusy calcite [15] has implications for unravelling the role of diagenetic paleofluids, as well as for improvements in the definition of paragenetic sequences in carbonate rocks and related reservoir-quality features. There are two possible interpretations of the formation of drusy dolomite cement: (1) Precipitation as cement, and (2) fabric-preserving dolomitization of precursor drusy mosaic calcite. Evidence supporting precipitation as drusy dolomite includes the sector cathodoluminescence zoning and its close association with the latter precipitated blocky calcite.

Fluid-inclusion microthermometry of drusy mosaic dolomite and the subsequently precipitated calcite cement indicate formation from hot brines during compressional tectonic events in conjunction with the obduction of Oman ophiolites [16,36]. However, it is not immediately clear whether the drusy mosaic dolomite has been precipitated as cement [13] or formed by dolomitization of drusy mosaic calcite by the hot basinal brines $[15,37]$. Drusy calcite is a common cement in limestones $[1,5-7,38]$. Thus, the common presence of drusy mosaic dolomite in totally dolomitized limestones may suggest formation by fabric-preserving dolomitization [15]. The latter process suggests similar dissolution rates of drusy calcite and precipitation rate of dolomite during the dolomitization process. A similar fabric-preserving dolomite of Bih Formation has been reported in earlier studies of carbonate reservoirs in the world [39-41].

The high $\mathrm{T}_{\mathrm{h}}\left(73\right.$ to $\left.233^{\circ} \mathrm{C}\right)$ and salinity $(20.8$ to $25.1 \mathrm{wt} \% \mathrm{NaCl}$ eq.) of drusy mosaic dolomite and subsequently precipitated cement indicates that they have precipitated either during deep-burial diagenesis or by upward flux of hydrothermal/hot basinal fluids [42]. 
The increase in $\mathrm{T}_{\mathrm{h}}$ with the increase in dolomite crystal size (av. 118 to $175.5^{\circ} \mathrm{C}$ ) is interpreted to indicate that the drusy dolomite precipitated with the increase in temperature during progressive burial. The maximum burial temperatures reached by the Bih Formation is approximately 190 to $200{ }^{\circ} \mathrm{C}$ [22]. The wide range of $T_{h}$ of different carbonate phases indicates that some fluid inclusions have been subjected to re-equilibration during burial processes [29]. The relatively systematic $\mathrm{T}_{\mathrm{h}}$ zoning from pore walls inwards (i.e., increase in crystal size) supports the formation of drusy dolomite by precipitation from pore fluids than by dolomitization of precursor drusy calcite cement. Apparently, the chemistry of the dolomitizing fluids has changed with time and reflected on the variation of Fe-rich and Fe-poor zoning of CL pattern of the drusy dolomite cement (cf., [2,36]).

The similar $\mathrm{T}_{\mathrm{h}}\left(148^{\circ} \mathrm{C}\right)$ and salinity values $(20.8 \mathrm{wt} \% \mathrm{NaCl}$ eq.) of late blocky calcite and fracture-filling medium to coarse calcite cement is attributed to the circulation of hot brines [17]. The considerably lower $\delta^{13} \mathrm{C}_{\mathrm{VPDB}}$ values $(-3.8 \%$ and $-0.9 \%$ o of fracture-filling calcite cement than drusy dolomite samples might indicate the deviation of dissolved carbon from degradation of hydrocarbons or organic matter [42]. Using the $\delta^{18} \mathrm{O}_{\mathrm{VPDB}}$ values $\left(-9.4 \%\right.$ to $-6.2 \%$ ) and $\mathrm{T}_{\mathrm{h}}\left(73\right.$ to $\left.233^{\circ} \mathrm{C}\right)$ of drusy dolomite, the fractionation equation of Land [43] it is inferred that precipitation has occurred from evolved brines $\left(\delta^{18} \mathrm{O}_{\text {VSMOW }}=+0.29 \%\right.$ o to $+10.96 \%$ o $)$. The wide extent of variations in the degree of geochemical evolution of the brines could be related to variable fluid sources and variable degrees of interaction with the host rocks in the basin. The positive correlation between $\mathrm{C}$ and $\mathrm{O}$ isotopes of drusy mosaic dolomite (Figure 7) suggests increasing input of ${ }^{12} \mathrm{C}$ into the formation waters with the increasing temperature [44]. The small variations in $\mathrm{Sr}$ isotopic compositions between the various types of carbonate cements suggest a related origin (Figure $8 \mathrm{~A}, \mathrm{~B}$ ). The ${ }^{87} \mathrm{Sr} /{ }^{86} \mathrm{Sr}$ ratios in one of the pebbles $(0.708202)$ is within the isotopic range of Permian to Triassic seawater values (0.7069 to 0.7083) [31]. The slightly higher ratio in another pebble sample (0.708424) than the range for Permo-Triassic seawater (Figure 8B) suggests that the hot basinal fluids have interacted with siliciclastic rocks $[45,46]$. The similar carbon isotope and ${ }^{87} \mathrm{Sr} /{ }^{86} \mathrm{Sr}$ ratio of drusy dolomite and coeval marine carbonates ([31]; 0.708106 and 0.708147 , respectively) suggests that dissolved carbon and Sr were derived from the dissolution of marine carbonates and/or marine pore waters. The slightly lower oxygen isotope value of drusy dolomite than coeval marine carbonates (Figure 8A) is attributed to precipitation at elevated temperatures.

The development of stylolites and dissolution seams along the rim of pebbles or cutting across both pebbles and dolomite between pebbles indicate that stylolitization postdates the drusy dolomite cement. This complex relationship between fracturing, stylolitization, and dolomite cementation may be caused by multiple phases of tectonic movements. The cross-cutting of low amplitude seams by high amplitude stylolites in conglomerate/breccia samples could be a result of increasing compressive stress by tectonic movements generated during the obduction of Oman ophiolites $[47,48]$. The presence of dolomite cement $\left(\mathrm{T}_{\mathrm{h}}\right.$ up to $190{ }^{\circ} \mathrm{C}$; salinity up to $20.8 \mathrm{wt} \% \mathrm{NaCl}$ eq.) along the stylolites suggests the flux of hot basinal brines and may indicate that the dolomite was precipitated by dolomitization of the host limestones prior to stylolitization. Dolomite cement apparently has been concentrated in the vicinity of the stylolitization surface as an insoluble residue (cf., [49]). Similar observations and interpretations have been presented for carbonate successions elsewhere [49-51]. The presence of clay minerals (locally pigmented by $\mathrm{TiO}_{2}$ ) along stylolites suggests that these minerals promoted the pressure dissolution of carbonates [52,53].

Constraining the depths at which the flux of hot dolomitizing basinal brines occurred is difficult without radiometric dating of dolomite [54,55]. However, the cross-cutting relationship between the stylolites and dolomite cement suggests that dolomitization took place at shallow depths [36].

\section{Conclusions}

The puzzling origin of pore-filling drusy mosaic dolomite cement in Permo-Triassic conglomerate/breccia beds outcropping in northern United Arab Emirates is constrained 
using the integrated field, petrographic, isotopic, and fluid-inclusion microthermometric analyses. There are two possible interpretations of the formation of drusy dolomite cement: (1) Precipitation as cement, and (2) fabric-preserving dolomitization of precursor drusy mosaic calcite. Fluid-inclusion microthermometry indicates the formation of this dolomite from hot basinal brines $\left(\mathrm{T}_{\mathrm{h}}=73\right.$ to $233{ }^{\circ} \mathrm{C}$; salinity $=21.8 \%$ to $25.1 \% \mathrm{wt} \% \mathrm{NaCl}$ eq.). Using the average homogenization temperature and oxygen isotope of dolomite $\delta^{18} \mathrm{O}_{\mathrm{VPDB}}$ $\left(-9.4 \%\right.$ to $-6.2 \%$ o the brines are inferred to be geochemically evolved with $\delta^{18} \mathrm{O}_{\mathrm{VSMOW}}$ $(+0.29 \%$ to $+10.96 \%$ o $)$. Lines of evidence supporting precipitation as drusy dolomite from pore waters include the sector cathodoluminescence zoning, the relatively systematic $T_{h}$ zoning, and with the presence of the latter precipitated blocky calcite, which has also precipitated from hot basinal brines $\left(\mathrm{T}_{\mathrm{h}}=148{ }^{\circ} \mathrm{C}\right.$ salinity $=20.8 \mathrm{wt} \% \mathrm{NaCl}$ eq. $)$. The construction of accurate paragenetic sequences is important for establishing exploration and production models for carbonate reservoirs. To achieve this goal, diagenesis should be linked to fluid history and tectonic evolution of the basin.

Author Contributions: H.M.: Conceptualization, Writing—original draft. M.A.: Writing-review \& editing. S.D.: Formal analysis, Methodology. S.S.: Writing—review \& editing, Visualization. S.M.: Writing-review \& editing, Supervision, Resources, Investigation. All authors have read and agreed to the published version of the manuscript.

Funding: This research received no external funding.

Institutional Review Board Statement: Not applicable.

Informed Consent Statement: Not applicable.

Data Availability Statement: Not applicable.

Acknowledgments: The fluid inclusion analyses were performed by Daniel Morad at the French Petroleum Institute, Paris, France, the carbon and oxygen isotope analyses at the Environmental Isotope laboratory, University of Waterloo, Canada, and the strontium isotope analyses at Bochum University, Germany.

Conflicts of Interest: The authors declare no conflict of interest.

\section{References}

1. Bathurst, R.G.C. Diagenesis in Mississippian Calcilutites and Pseudobreccias. J. Sediment. Res. 1959, 29, 365-376. [CrossRef]

2. Tucker, M.E.; Wright, V.P. Diagenetic Processes, Products and Environments. Carbonate Sedimentol. 2009, 482, 314-364. [CrossRef]

3. Friedman, G.M. Early Diagenesis and Lithification in Carbonate Sediments. J. Sediment. Res. 1964, 34, 777-813. [CrossRef]

4. Gavish, E.; Friedman, G.M. Progressive diagenesis in Quaternary to Late Tertiary carbonate sediments: Sequence and time scale. J. Sediment. Res. 1969, 39, 980-1006.

5. Dodd, J.R. Processes of Conversion of Aragonite to Calcite with Examples from the Cretaceous of Texas. J. Sediment. Res. 1966, 36, 36. [CrossRef]

6. Rousseau, M.; Dromart, G.; Garcia, J.-P.; Atrops, F.; Guillocheau, F. Jurassic evolution of the Arabian carbonate platform edge in the central Oman Mountains. J. Geol. Soc. 2005, 162, 349-362. [CrossRef]

7. Tackett, L.S.; Bottjer, D.J. Paleoecological succession of norian (late triassic) benthic fauna in eastern panthalassa (luning and gabbs formations, west-central nevada). PALAIOS 2016, 31, 190-202. [CrossRef]

8. Lohmann, K.C.; Walker, J.C.G. Secular variation in $13 \mathrm{C}$ and $16 \mathrm{O}$ composittion of phamerozoic oceans. Geol. Soc. Am. Abstr. Prog. 1984, 16, 578 .

9. Carpenter, S.J.; Lohmann, K.C. Delta 18 and delta 13 C variations in Late Devonian marine cements from the Golden Spike and Nevis reefs, Alberta, Canada. J. Sediment. Res. 1989, 59, 792-814. [CrossRef]

10. Scholle, P.A.; Ulmer-Scholle, D.S. A Color Guide to the Petrography of Carbonate Rocks: Grains, Textures, Porosity, Dia-Genesis, AAPG Memoir 77; AAPG: Tulsa, OK, USA, 2003.

11. Morad, S.; Al-Aasm, I.S.; Nader, F.H.; Ceriani, A.; Gasparrini, M.; Mansurbeg, H. Impact of diagenesis on the spatial and temporal distribution of reservoir quality in the Jurassic Arab D and C members, offshore Abu Dhabi oilfield, United Arab Emirates. GeoArabia 2010, 17, 17-56.

12. Mattavelli, L.; Chilingarian, G.; Storer, D. Petrography and diagenesis of the taormina formation, gela oil field, sicily (Italy). Sediment. Geol. 1969, 3, 59-86. [CrossRef]

13. Chatalov, A.; Bonev, N.; Ivanova, D. Depositional characteristics and constraints on the mid-Valanginian demise of a car-bonate platform in the intra-Tethyan domain, Circum- Rhodope Belt, northern Greece. Cretaceous Res. 2015, 55, 84-115. [CrossRef] 
14. Gariboldi, K.; Gioncada, A.; Bosio, G.; Malinverno, E.; Di Celma, C.; Tinelli, C.; Cantalamessa, G.; Landini, W.; Urbina, M.; Bianucci, G. The dolomite nodules enclosing fossil marine vertebrates in the East Pisco Basin, Peru: Field and petrographic insights into the Lagerstätte formation. Palaeogeogr. Palaeoclim. Palaeoecol. 2015, 438, 81-95. [CrossRef]

15. Mansurbeg, H.; Morad, D.; Othman, R.; Morad, S.; Ceriani, A.; Al-Aasm, I.; Kolo, K.; Spirov, P.; Proust, J.N.; Preat, A.; et al. Hydrothermal dolomitization of the Bekhme formation (Upper Cretaceous), Zagros Basin, Kurdistan Region of Iraq: Record of oil migration and degradation. Sediment. Geol. 2016, 341, 147-162. [CrossRef]

16. Callot, J.P.; Breesch, L.; Guilhaumou, N.; Roure, F.; Swennen, R.; Vilasi, N. Paleo-fluids characterisation and fluid flow modelling along a regional transect in Northern United Arab Emirates (UAE). Arab. J. Geosci. 2010, 4, 413-437. [CrossRef]

17. Fontana, S.; Nader, F.; Morad, S.; Ceriani, A.; Daniel, J.-M.; Mengus, J.-M.; Al-Aasm, I.S. Fluid-rock interactions associated with regional tectonics and basin evolution. Sedimentology 2013, 61, 660-690. [CrossRef]

18. Maurer, F.; Rettori, R.; Martini, R. Triassic stratigraphy, facies and evolution of the Arabian shelf in the northern United Arab Emirates. Int. J. Earth Sci. 2008, 97, 765. [CrossRef]

19. Searle, M.P. Thrust tectonics of the Dibba zone and the structural evolution of the Arabian continental margin along the Musandam Mountains (Oman and United Arab Emirates). J. Geol. Soc. 1988, 145, 43-53. [CrossRef]

20. Strohmenger, C.J.; Alway, R.H.; Broomhall, R.W.; Hulstrand, R.F.; Al-Mansoori, A.; Abdalla, A.A.; Al-Aidarous, A. Sequence stratigraphy of the Khuff Formation comparing subsurface and outcrop data. In Proceedings of the Abu Dhabi International Petroleum Exhibition and Conference, Abu Dhabi, United Arab Emirates, 13 October 2002.

21. Maurer, F.; Martini, R.; Rettori, R.; Hillgärtner, H.; Cirilli, S. The geology of Khuff outcrop analogues in the Musandam Peninsula, United Arab Emirates and Oman. GeoArabia 2009, 14, 125-158.

22. Fontana, S.; Morad, S.; Nader, F.H.; Ceriani, A.; Al-Aasm, I.S. Breccia beds in the Khuff (Permian-Triassic) in Ras Al Khaimah, United Arab Emirates: Collapse or transgressive in origin? In the Permo-Triassic Sequence of the Arabian Plate, Abstracts of the EAGE's Third Arabian Plate Geology Workshop, Kuwait. Abstract. GeoArabia J. Middle East Pet. Geosci-Ences. 2012, 17, 225-230.

23. Fontana, S.; Morad, S.; Nader, F.H.; Al-Aasm, I.S.; Ceriani, A. Diagenesis of the Permo-triassic Succession of the Northeastern UAE, an Outcrop Analogue of the Khuff Formation. In Proceedings of the 73rd EAGE Conference and Exhibition Incorporating SPE EUROPEC, Vienna, Austria, 23-26 May 2011; p. 238. [CrossRef]

24. Warburton, J.; Burnhill, T.; Graham, R.; Isaac, K. The Evolution of the Oman Mountains Foreland Basin; Geological Society, Special Publications: London, UK, 1990; Volume 49, pp. 419-427.

25. Breesch, L.; RSwennen, B.; Dewever, F.; Roure, B. Vincent. Diagenesis and fluid system evolution in the northern Oman Mountains, United Arab Emirates: Implications for petroleum exploration. GeoArabia 2011, 16, 111-148.

26. Breesch, L.; Swennen, R.; Vincent, B. Fluid flow reconstruction in hanging and footwall carbonates: Compartmentalization by Cenozoic reverse faulting in the Northern Oman Mountains (UAE). Mar. Pet. Geol. 2009, 26, 113-128. [CrossRef]

27. Michaelis, P.; Pauken, R. Seismic Interpretation of the Structure and Stratigraphy of the Strait of Hormuz; Geological Society, Special Publications: London, UK, 1990; Volume 49, pp. 387-395.

28. Searle, M.P.; James, N.P.; Calon, T.J.; Smewing, J.D. Sedimentological and structural evolution of the Arabian continental margin in the Musandam Mountains and Dibba zone, United Arab Emirates. GSA Bull. 1983, 94, 1381. [CrossRef]

29. Goldstein, R.H.; Reynolds, T.J. Systematics of fluid inclusions in diagenetic minerals. SEPM Short Course 1994, 31, 199.

30. Bodnar, R. Revised equation and table for determining the freezing point depression of H2O-Nacl solutions. Geochim. Cosmochim. Acta 1993, 57, 683-684. [CrossRef]

31. Veizer, J.; Ala, D.; Azmy, K.; Bruckschen, P.; Buhl, D.; Bruhn, F.; Godderis, Y. 87Sr/86Sr, $\delta 13 \mathrm{C}$ and $818 \mathrm{O}$ evolution of Phan-erozoic seawater. Chem. Geol. 1999, 161, 59-88. [CrossRef]

32. Epstein, S.; Buchsbaum, R.; Lowenstam, H.A.; Urey, H.C. Revised carbonate-water Isotopic Temperature Scale. Geol. Soc. Am. Bull. 1953, 64, 1315-1326. [CrossRef]

33. Savard, M.M.; Veizer, J.; Hinton, R. Cathodoluminescene at low Fe and Mn concentrations; a SIMS study of zones in natural calcites. J. Sediment. Res. 1995, 65, 208-213. [CrossRef]

34. Pierson, B.J. The control of cathodoluminescence in dolomite by iron and manganese. Sedimentology 1981, 28, 601-610. [CrossRef]

35. Carmichael, S.K.; Ferry, J.M. Formation of replacement dolomite in the Latemar carbonate buildup, Dolomites, northern Italy: Part Origin of the dolomitizing fluid and the amount and duration of fluid flow. Am. J. Sci. 2008, 308, 885-904. [CrossRef]

36. Fontana, S.; Nader, F.H.; Morad, S.; Ceriani, A.; Al-Aasm, I.S. Diagenesis of the Khuff Formation (Permian-Triassic), Northern United Arab Emirates. In Frontiers in Earth Sciences; Springer: Berlin/Heidelberg, Germany, 2013; pp. $203-220$.

37. Philip, J.M.; Gari, J. Late Cretaceous heterozoan carbonates: Palaeoenvironmental setting, relationships with rudist carbonates (Provence, south-east France). Sediment. Geol. 2005, 175, 315-337. [CrossRef]

38. Fairchild, I.J.; Humbrey, M.J. The Vendian succession of northeastern Spitsbergen: Petrogenesis of a dolomite-tillite association. Precambrian Res. 1984, 26, 111-167. [CrossRef]

39. Kimbell, T.N. Sedimentology and Diagenesis of Late Pleistocene Fore-Reef Calcarenites, Barbados, West Indies: A Geo-Chemical and Petrographic Investigation of Mixing Zone Diagenesis. Ph.D. Thesis, The University of Texas at Dallas, Dallas, TX, USA, 1993; p. 296.

40. Cantrell, D.; Peter, S.; Royal, H. Genesis and characterization of dolomite, Arab-D reservoir, Ghawar field, Saudi Arabia. GeoArabia 2004, 9, 11-36. 
41. Hutsky, A.J.; Fielding, C.R.; Frank, T.D. Evidence for a petroleum subsystem in the Frontier Formation of the Uinta-Piceance Basin petroleum province. AAPG Bull. 2016, 100, 1033-1059. [CrossRef]

42. Morad, S.; De Ros, L.F.; Nystuen, J.P.; Bergan, M. Carbonate Diagenesis and Porosity Evolution in Sheet-Flood Sandstones: Evidence from the Middle and Lower Lunde Members (Triassic) in the Snorre Field, Norwegian North Sea. In Carbonate Cementation in Sandstones; Wiley: Hoboken, NJ, USA, 2009; Volume 26, pp. 53-85.

43. Land, L.S. The application of stable isotopes to studies of the origin of dolomite and to problems of diagenesis of clastic sedi-ments. In Stable Isotopes in Sedimentary Geology; Arthur, M.A., Anderson, T.F., Kaplan, I.R., Veizer, J., Land, L.S., Eds.; Special Publications of SEPM: Tulsa, OK, USA, 1983; Volume 10, pp. 41-422.

44. Morad, S. Carbonate Cementation in Sandstones: Distribution Patterns and Geochemical Evolution (Special Publication 26 of the IAS); John Wiley \& Sons: Hoboken, NJ, USA, 2008; p. 72.

45. Davies, G.R.; Smith, L.B. Structurally controlled hydrothermal dolomite reservoir facies: An overview. AAPG Bull. 2006, 90, 1641-1690. [CrossRef]

46. Gasparrini, M.; Bechstädt, T.; Boni, M. Massive hydrothermal dolomites in the southwestern Cantabrian Zone (Spain) and their relation to the Late Variscan evolution. Mar. Pet. Geol. 2006, 23, 543-568. [CrossRef]

47. Sirat, M.; Al-Aasm, I.; Morad, S.; Aldahan, A.; Al-Jallad, O.; Ceriani, A.; Morad, D.; Mansurbeg, H.; Al Suwaidi, A. Saddle dolomite and calcite cements as records of fluid flow during basin evolution: Paleogene carbonates, United Arab Emirates. Mar. Pet. Geol. 2016, 74, 71-91. [CrossRef]

48. Morad, D.; Nader, F.; Gasparrini, M.; Morad, S.; Rossi, C.; Marchionda, E.; Al Darmaki, F.; Martines, M.; Hellevang, H. Comparison of the diagenetic and reservoir quality evolution between the anticline crest and flank of an Upper Jurassic carbonate gas reservoir, Abu Dhabi, United Arab Emirates. Sediment. Geol. 2018, 367, 96-113. [CrossRef]

49. Paganoni, M.; Al Harthi, A.; Morad, D.; Morad, S.; Ceriani, A.; Mansurbeg, H.; Al Suwaidi, A.; Al-Aasm, I.S.; Ehrenberg, S.N.; Sirat, M. Impact of stylolitization on diagenesis of a Lower Cretaceous carbonate reservoir from a giant oilfield, Abu Dhabi, United Arab Emirates. Sediment. Geol. 2016, 335, 70-92. [CrossRef]

50. Braithwaite, C. Stylolites as open fluid conduits. Mar. Pet. Geol. 1989, 6, 93-96. [CrossRef]

51. Neilson, J.E.; Oxtoby, N.H.; Simmons, M.D.; Simpson, I.R.; Fortunatova, N.K. The relationship between petroleum emplace-ment and carbonate reservoir quality: Examples from Abu Dhabi and the Amu Darya Basin. Mar. Pet. Geol. 1998, 15, 57-72. [CrossRef]

52. Aharonov, E.; Katsman, R. Interaction between pressure solution and clays in stylolite development: Insights from modeling. Am. J. Sci. 2009, 309, 607-632. [CrossRef]

53. Ehrenberg, S.N.; Morad, S.; Yaxin, L.; Chen, R. Stylolites and Porosity in A Lower Cretaceous Limestone Reservoir, Onshore Abu Dhabi, U.A.E. J. Sediment. Res. 2016, 86, 1228-1247. [CrossRef]

54. Salih, N.; Mansurbeg, H.; Kolo, K.; Préat, A. Hydrothermal Carbonate Mineralization, Calcretization, and Microbial Diagenesis Associated with Multiple Sedimentary Phases in the Upper Cretaceous Bekhme Formation, Kurdistan Region-Iraq. Geoscience 2019, 9, 459. [CrossRef]

55. Mansurbeg, H.; Alsuwaidi, M.; Salih, N.; Shahrokhi, S.; Morad, S. Integration of stable isotopes, radiometric dating and mi-crothermometry of saddle dolomite and host dolostones (Cretaceous carbonates, Kurdistan, Iraq): New insights into hydrothermal dolomitization. Mar. Pet. Geol. 2021, 127, 104989. [CrossRef] 